\title{
Studies of Nucleosides and Nucleotides. LVI.1) A Versatile Method for the Synthesis of 8-Mercaptoadenosine Nucleotides
}

\author{
Morio Ikehara, Eiko Ohtsuka, and Seirchi Uesugi \\ Faculty of Pharmaceutical Sciences, Osaka University ${ }^{2}$
}

(Received September 7, 1972)

We have reported the syntheses of various 8 -substituted purine nucleosides ${ }^{3-5)}$ and nucleotides, ${ }^{6-9)}$ as well as polynucleotides. ${ }^{10}$ ) The key intermediates 8-bromo derivatives were transformed to 8-mercapto compounds by refluxing with thiourea or by heating with $\mathrm{H}_{2} \mathrm{~S}$ in pyridine solution. In this paper we describe a versatile method for obtaining 8-mercaptoadenosine derivatives from the corresponding 8-bromo compounds using $\mathrm{NaSH}$ in DMFwater solution at room temperature. The yield was generally high and side reactions were limited.

By using this method 8-mercapto AMP, 3',5'-cyclic 8-mercapto AMP and 8-mercapto ATP were obtained in the yield of 79,76 , and $78 \%$, respectively. 8-Mercapto ATP, thus obtained, was used for the substrate of RNA pyrophosphorylase ${ }^{\mathbf{1 1})}$ and $3^{\prime}, 5^{\prime}$-cyclic 8-mercaptoAMP was used for rat liver protein kinase $B_{2} \cdot{ }^{12}$

\section{Experimental}

8-Mercaptoadenosine 5'-Monophosphate--8-Bromo-5'-AMP $\mathrm{NH}_{4}$ salt ${ }^{7}$ ) (1 mmole) was dissolved in DMF-water $(1: 1, \mathrm{vol} / \mathrm{vol})(7 \mathrm{ml})$. Into the solution was added $40 \% \mathrm{NaSH}(0.7 \mathrm{ml})$ and the reaction mixture was kept at room temperature for $21 \mathrm{hr}$. After the reaction extent was examined by paper electrophoresis (pH 7.5), the mixture was neutralized with $0.1 \mathrm{~N} \mathrm{HCl}$. Solvent was evaporated in vacuo, a small amount of water was added, and filtered. Filtrate was evaporated in vacuo and residue was dissolved in water. The water solution was applied to a DEAE-cellulose (bicarbonate form) column $(2 \times 50 \mathrm{~cm})$. The column was eluted with triethylammonium bicarbonate buffer ( $\mathrm{pH} 7.5)(0.01-0.2 \mathrm{M}, 31+3 \mathrm{l})$, using linear gradient technique. Fractions $(20 \mathrm{ml}$ each) No. 156-320 were collected and evaporated. After the evaporation with added water several times, the solution was lyophilized. Yield was $79 \%$. UV: $\lambda_{\max }^{\text {pH }} 2308 \mathrm{~nm}(2.74 \times$ $\left.10^{4}\right), \lambda_{\max }^{\mathrm{pH}} 298 \mathrm{~nm}\left(2.74 \times 10^{4}\right), \lambda_{\max }^{\mathrm{pH}}{ }_{11} 296 \mathrm{~nm}\left(2.59 \times 10^{4}\right)$. Paper chromatography $\left(R_{\mathrm{pA}}\right):$ in solvent $\left.\mathrm{A},{ }^{13}\right) 1.34$; solvent $\mathrm{B}, 0.61$; solvent $\mathrm{C}, 0.66$. Paper electrophoresis performed in $0.05 \mathrm{~m}$ ammonium bicarbonate at $\mathrm{pH}$ $7.5: R_{\mathrm{pA}} 1.25$.

8-Mercaptoadenosine 5'-Triphosphate-8-Bromoadenosine 5'-triphosphate ${ }^{9}$ ) (Li salt) (30 mg, $690 \mathrm{~A}_{26.5}$ units, $0.043 \mathrm{mmole})$ was dissolved in a mixture of DMF $(0.35 \mathrm{ml})$ and water $(0.35 \mathrm{ml})$. Aqueous sodium hydrogensulfide $(40 \%)(90 \mu \mathrm{l})$ was added to the mixture and an additional water $(0.35 \mathrm{ml})$ was added to dissolve precipitates. After $16 \mathrm{hr}$ at $25^{\circ}$ paper electrophoresis showed no starting material $\left(R_{\mathrm{pA}} 1.53\right)$. The spot

1) Part LV: M. Ikehara and S. Uesugi, Chem. Pharm. Bull. (Tokyo), 20, 2394(1972).

2) Location: Toyonaka, Osaka.

3) M. Ikehara and K. Muneyama, Chem. Pharm. Bull. (Tokyo), 14, 46(1966).

4) M. Ikehara and H. Tada, Tetrahedron, 24, 3489 (1968).

5) M. Ikehara and S. Yamada, Chem. Pharm. Bull. (Tokyo), 19, 104(1971).

6) M. Ikehara and K. Murao, Chem. Pharm. Bull. (Tokyo), 16, 1330(1968).

7) M. Ikehara and S. Uesugi, Chem. Pharm. Bull. (Tokyo), 17, 348 (1969).

8) M. Ikehara, I. Tazawa, and T. Fukui, Chem. Pharm. Bull. (Tokyo), 17, 1619(1969).

9) H. Uno, S. Oyabu, E. Ohtsuka, and M. Ikehara, Biochim. Biophys. Acta, 228, 282 (1971).

10) M. Ikehara, I. Tazawa, and T. Fukui, Biochemistry, 8, 736(1969).

11) S. Takemura, unpublished experiment.

12) Y. Nishizuka, unpublished experiment.

13) Solvent A: $n$-Butanol-acetic acid- $\mathrm{H}_{2} \mathrm{O}(5: 2: 3, \mathrm{v} / \mathrm{v}), \mathrm{B}: n$-propanol-conc. $\mathrm{NH}_{3}-\mathrm{H}_{2} \mathrm{O}(55: 10: 35, \mathrm{v} / \mathrm{v})$, $\mathrm{C}$ : ethanol-1 $\mathrm{m}$ ammonium acetate $(7: 3, \mathrm{v} / \mathrm{v})$, D: sat. ammonium sulfate-isopropanol-conc. ammonic $(79: 19: 2, \mathrm{v} / \mathrm{v})$. 
$\left(R_{\mathrm{vA}} 1.60\right)$ showed ultraviolet (UV) spectrum similar to 8 -mercaptoadenosine. The reaction mixture was adjusted to $\mathrm{pH} 6$ with $2 \mathrm{~N} \mathrm{HCl}$ and nitrogen gas was passed through the solution. The solution was again adjusted to $\mathrm{pH} 7.5$ with $2 \mathrm{~N} \mathrm{NaOH}$ and concentrated to $c a .5 \mathrm{ml}$. The concentrated solution was applied to a column $(2 \times 60 \mathrm{~nm})$ of Biogel P-2. Fractions of $3 \mathrm{ml}$ were collected and fractions $23-37$ were combined. The yield was $890 \mathrm{~A}_{298}$ units $0.033 \mathrm{mmole}, 78 \%$. UV: $\lambda_{\max }^{\mathrm{pH} 2} 261,236 \mathrm{~nm} ; \lambda_{\mathrm{max}}^{\mathrm{pH}} 254 \mathrm{~nm} ; \lambda_{\max }^{\mathrm{pH} 13} 296 \mathrm{~nm} ; \lambda_{\mathrm{max}}^{\mathrm{pH} 2} 261$, $236 \mathrm{~nm} ; \lambda_{\max }^{\mathrm{pH} 7} 254 \mathrm{~nm} ; \lambda_{\max }^{\mathrm{pH} 13} 253 \mathrm{~nm}$. Paper chromatography in solvent $\mathrm{B}: R_{\mathrm{pA}}=0.40$, in solvent $\mathrm{D}: R_{\mathrm{pA}}=1.74$.

8-Mercaptoadensoine 3',5'-Cyclic Phosphate-8-Bromoadenosine-3',5'-cyclic phosphate $\left.{ }^{7}\right)(100 \mathrm{mg})$ was dissolved in a mixture of DMF $(0.3 \mathrm{ml})$ and water $(0.3 \mathrm{ml})$. Aqueous sodium hydrogen sulfide (407, $100 \mu \mathrm{l}$ ) was added to the mixture. After $15 \mathrm{hr}$ at $25^{\circ}$, paper electrophoresis showed almost complete conversion of the starting material. The reaction mixture was adjusted to $\mathrm{pH} 7$ with $2 \mathrm{~N} \mathrm{HCl}$ and nitrogen gas was passed through the solution, which was adjusted to $\mathrm{pH} 7.5$ with $2 \mathrm{~N} \mathrm{NaOH}$. The solution was applied to a column $(2 \times 50 \mathrm{~cm})$ of DEAE-cellulose (bicarbonate form). The column was eluted with triethylammonium bicarbonate buffer $(\mathrm{pH} 7.5,0.01-0.1 \mathrm{M}, 21+21)$ using linear gradient technique. Fractions (10 inl each) 58-120 were collected and evaporated. Evaporation was repeated several times with added water and final solution was lyophilized to give a powder. Yield was $76 \%$ UV: $\lambda_{\max }^{\text {pH } 1} 220,244,308 \mathrm{~m} \mu$; $i_{\max }^{\mathrm{H}_{2} \mathrm{O}} 221,245,310 \mathrm{~m} \mu: \lambda_{\max }^{\mathrm{HH} 11} 224,290 \mathrm{~nm} . \quad$ PPC: $R_{\mathrm{pA}}$ in solvent A 1.65 and in solvent B 0.65 . These properties were identical to those reported by Muneyama, et al. ${ }^{14)}$

14) K. Muneyama, R.J. Bauer, D.S. Shuman, R. K. Robins, and L.N. Simon, Biochemistry, 10, 2390 (1971).

\title{
Phosphorylation by Active Ester of Phosphoric Acid. I. Preparation and Reaction of Phenyl 8-Quinolyl Phosphate ${ }^{1)}$
}

\author{
Hiroshi Takaku and Yoshifusa Shimada \\ Dcpartment of Chemistry, Chiba Institute of Technology $y^{2)}$
}

(Received July 14, 1972)

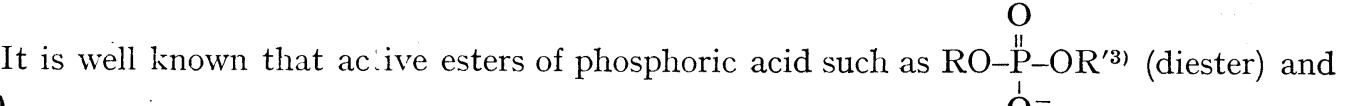
$\mathrm{O}$

$R O P_{-N}^{\prime \prime} R^{\prime} R^{\prime 4)}$ (phosph samidate) are important intermediates in the synthesis of various $\mathrm{O}^{-}$

kinds of phosphoric acid derivatives.

In the present study, the preparation of phenyl 8-quinolyl phosphate (4) and the reactions of the active diester of phosphoric acid (4) with alcohols and amines were investigated. It was considered that the phosphate $(\mathbf{4})$ would yield a reactive intermediate $\left(\mathbf{4}^{\prime}\right)$, which in turn would further react with alcohols to give diesters of phosphoric acid as shown in Chart1. The synthesis of diester of phosphoric acid can be effected successfully by this method since it reacts exclusively with nucleophilic reagents such as alcohols and amines under mild conditions.
\end{abstract}

1) Part of this work was presented at the 90th Annual Meeting of the Pharmaceutical Society of Japan, Sapporo, July 1970.

2) Location: Narashino-shi, Chiba.

3) a) W. Kampe, Chem. Ber., 98, 1031 (1965); b) W. Kampe, ibid., 98, 1038(1965); c) K.H. Scheit and IV. Kampe, ibid., 98, 1045 (1965).

4) F. Cramer, H. Schaller, and H.A. Staab, Chem. Bev., 94, 1612 (1961); H. Schaller, H.A. Staab, and F. Cramer, ibid., 94, 1621 (1961); F. Cramer and H. Schaller, ibid., 94, 1634 (1961); J.G. Moffatt and H.G. Khorana, J. Amer. Chem. Soc., 83, 649 (1961). 